\title{
A STUDY ON THE DETERMINANTS OF FINANCIAL PERFORMANCE OF U.S. AGRICULTURAL COOPERATIVES
}

\author{
Kuldeep SINGH ${ }^{(D *}$, Madhvendra MISRA, Mohit KUMAR, Vineet TIWARI \\ Department of Management Studies, Indian Institute of Information Technology, \\ Allahabad, India
}

Received 13 November 2018; accepted 04 March 2019

\begin{abstract}
A significant number of studies have been made in the area of agricultural economics; however, there is a paucity of work that investigates factors or determinants which influence the financial performance of agro cooperatives. This paper investigates determinants of financial performance for the United States (U.S.) agricultural cooperatives for the period 2009-2017. By using the United States Department of Agriculture (USDA) database, we created a sample of 37 U.S. agro cooperatives. For analysis, we used panel regression analysis as it is suitable to deal with fixed effect or random effect error component presented in the model. Finding states that the U.S. agro cooperatives are found highly sensitive to economic policy uncertainty. The results provide evidence of a negative relationship between size and profitability. Moreover, the impact of growth and capital intensity is also reflected in the return on asset (ROA). In this study, we considered ROA as a proxy for firm performance. Implications and suggestions for further new research are also discussed.
\end{abstract}

Keywords: agricultural cooperatives, financial performance, economic policy uncertainty, return on asset (ROA), United States (U.S.), capital intensity.

JEL Classification: M21, P34, Q13, Q14.

\section{Introduction}

Agricultural cooperatives are prominent organizational firms which have played an important economic role in agricultural markets all over the world (Franken \& Cook, 2015). Furthermore, at the time of crisis, these agro cooperatives are found to be resilient as they follow appropriate mechanism for their survival (Kontogeorgos, Sergaki, Kosma, \& Semou, 2018; Rakopoulos, 2014; Birchall \& Ketilson, 2009). The emergence of agricultural cooperatives from the end of the $18^{\text {th }}$ century was a user-owned and user controlled business that shares return equally on the basis of use or patronage (Shannon, 2017). Business economics literature also explains the existence and importance of such cooperatives, through their

\footnotetext{
*Corresponding author. E-mail: rsm2017001@iiita.ac.in
} 
performance in financial terms and various other aspects such as ideology, commitment, and values (Bonus, 1986; Staatz, 1987; Hansmann, 1988). However, by recognizing the institutional advantages of agro cooperatives, these explanations raise the question of how agro cooperatives are continually existing and performing from $18^{\text {th }}$ century till present times. It is the main contention of this paper to investigate the determinants of financial performance of agricultural cooperatives. Present study made in the context of U.S. where agricultural cooperatives are the main sector of the agricultural economy providing many economic benefits to the nation.

The early 20th century, U.S. agricultural cooperatives have struggled to become increasingly efficient and grown dramatically in the national and the rural economies (USDA, 2011). Since then, many economists have given their considerable attention to analyze and understand the problems related to the agriculture cooperatives and proposing different policy alternatives for their solution (Schuh, 1974). United States Department of Agriculture (USDA) has also issued several reports indicated that financial issues faced by different agricultural cooperatives in the U.S. are the current theme of their research than news of their successes (Beranová \& Basovníková, 2014). Although in agricultural economics, performance evaluation has always been a topic of considerable interest in both developed and developing countries.

Every year, USDA conducts an annual survey of agricultural cooperatives. These survey reports have shown that the number of agricultural cooperatives in the U.S. continues to decline, but on the other side, their gross volume is continuously going up. During the period 2000-2016, the numbers of agricultural cooperatives have dropped from 3338 to just over 1953. During the same period, the gross volume has gone up from $\$ 118.9$ billion to $\$ 191.1$ billion. The trends toward fewer (number of cooperatives) and larger (gross volume) agro cooperatives is reliable to know about the determinants contributed to such change. The U.S. cooperatives' degree of success is often reflected in the financial performance which traditionally measured in the form of accounting ratios. As per earlier studied the role of technology is well documented for such change. Other factors which have contributed can be financial determinants, uncertainty, institutional innovations and human capital productivity (Mishra \& Morehart, 2001).

As financial performance has been studied so many years for different cross-industry firms (Ozkan \& Ozkan, 2004; Opler, Pinkowitz, Stulz, \& Williamson, 1999; Kim, Mauer, \& Sherman, 1998; Bates, Kahle, \& Stulz, 2009; Martinkute-Kauliene, 2014; Pinkowitz \& Williamson, 2001), no much study has been found on agricultural cooperatives. Therefore, with this study, we try to address the gap and also analyzing the determinants of financial performance for agro-cooperatives. The following sections review the literature on agro cooperatives, setting the background for the empirical analysis. Afterward, the paper outlines the results of the study and, finally, discussion and conclusions are made along with the suggestions for future research. 


\section{Literature review}

The cooperative business model provides people with little or no capital a pool of resources that helps in generating employment and economic development. With more than one billion members across the world, cooperative organizations help in contributing livelihoods of around 3 billion people i.e. three times to its member associated and creating jobs for more than hundred million (International Labor Organization, 2014). Cooperatives to become competitive in the markets do not adopt sheer profiteering but, run on values that make it competitive and strong enough to beat the market peculiarities and to sustain for a longer period (Sisay, Verhees, \& Van Trijp, 2017). A broad set of values among cooperative enterprises consist of features like democracy, equality, responsibility, equity, and self-help, etc. By virtue of its democracy, equity and equality, cooperative enterprises are able to manage their needs of profitability along with the needs of their members and personal or professional interest of community (Rothschild \& Whitt, 1989). Cooperative form of business model serves in almost every sector of the economy, with different needs and aspirations of people around the globe (Liebrand, 2007). In the present study, the cooperative form of business enterprises in the U.S. (especially practicing in agriculture, dairy, and food) is taken into consideration, with the objective to analyze their performance in financial terms and coping with economic policy uncertainties (Chaddad, Cook, \& Heckelei, 2005). Institutional histories in the U.S. emphasize the rise and development of corporations as U.S. capitalism's basic tendency of organizational formation and business model, but yet farmers' alliances and small business groups had put their efforts in establishing cooperatives as decentralized and regional based enterprises alternatives to the large centrally located corporations (Cook, 1995). The United States has three industry types of cooperative businesses, "insurance," "dairy," and "grain cooperatives." And these cooperatives are continually existing and performing from 18th century till present times (Schneiberg, King, \& Smith, 2008). In most empirical work, agrocooperatives are conceptualized as an independent firm and thus analyzing ROE places more emphasis on management to generate ROI, not necessarily a return on patronage (Grashuis, 2018). Here, we review the literature related to different determinants which impact the performance of U.S. agro cooperatives.

1.1. Size: Previous studies on the financial performance of cooperatives often stressed the size of the cooperative business firm. The earlier literature states that larger cooperatives are found to be more efficient in utilizing their assets than smaller cooperatives. On the other side, smaller cooperatives found to have higher profitability than larger ones. The earlier results suggest that large cooperatives may enjoy the economies of scale in terms of efficiency, but the benefits of size do not necessarily translate into higher profitability. As per liquidity, it is found that small cooperatives prefer to maintain higher liquidity than large ones (Levy \& Lerman, 1985).

1.2. Growth: There have been several studies published on high-growth cooperatives; worker cooperatives (Amat \& Perramon, 2011), agro cooperatives (Caves \& Petersen, 1986), service cooperatives (Deininger, 1995). According to Amat and\& Perramon, (2011), among different high growth factors, strategic management, quality, innovation, customer satisfaction, and relative financial policies would help to provide an excellent growth achievement. 
Deininger (1995) found the key factors for high growth cooperatives are training and development, quality control, and productivity followed by innovation and the legal practices.

1.3. Leverage: The relationship between firm performance and leverage policy has gained little attention in the finance literature. This is because there is an existence of an association between financial performance and debt policy of the firm (Amat \& Perramon, 2011). However, high-growth cooperatives are found to have lower financial leverage as external financing involves higher cost and also increase a risk that entails if incomes decline in the future so will profitability. Furthermore, agricultural cooperatives have achieved a higher performance with lower leverage, and they are better prepared to face any future uncertainty (Lerman \& Parliament, 1991).

1.4. Capital Intensity: The U.S. economy is classified as a capitalist economy supporting corporate culture rather cooperative forms (Schneiberg et al., 2008). However, after the 18th century, U.S. capitalism started to support the cooperatives and other family types of business model and because of those reasons; only cooperative enterprises have started during the 18th century performing well till present times. FitzRoy and Kraft (1987) found that larger cooperatives are having lower capital intensity than smaller ones. However, some theoretical and empirical study provides evidence for a positive impact of capital intensity on firm performance (Harris, 1994).

1.5. Uncertainty: Many studies have been made on firm-level uncertainty or aggregate uncertainty concerning the financial performance of the firms (Acharya, Almeida, \& Campello, 2013; Bates et al., 2009; Duchin, 2010; Foley, Hartzell, Titman, \& Twite, 2007; Gao, Grinstein, \& Wang, 2014; Martinkute-Kauliene, 2012; Pinkowitz, Stulz, \& Williamson, 2012). In this paper we tried to investigate the relationship between uncertainty measured by economic policy uncertainty as an EPU index (Baker, Bloom, \& Davis, 2016), and the return on asset (ROA), using the approach used in Kang \& Ratti (2013), Antonakakis, Chatziantoniou, \& Filis (2013), Liu and Zhang (2015). From the results, the authors found an inverse relationship between uncertainty and ROI (Figure 1).

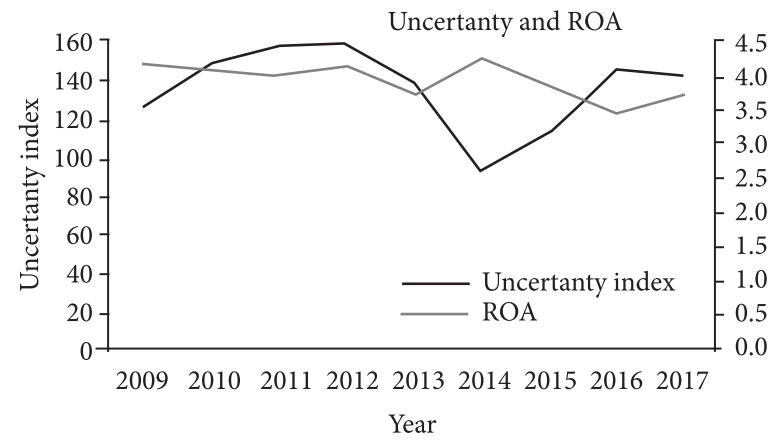

Figure 1. Uncertainty and Returns ${ }^{1}$ (Source: composed by the authors according to USDA reports and Economic Policy Uncertainty Database)

\footnotetext{
${ }^{1}$ Figure 1 depicts the economic policy uncertainty index (the left axis), the return on asset (ROA) (the right axis).
} 
The uncertainty index, we used in this study has been evaluated in several ways. Mainly, it is based on an extensive audit study of 12000 articles which were randomly selected from 10 leading U.S. newspapers: Chicago Tribune, USA Today, Boston Globe, Miami Herald, Washington Post, Wall Street Journal, Dallas Morning News, San Francisco Chronicle, Los Angeles Times, and New York Times. Search has been made through the digital archive of each paper to obtain the articles which contain the following keywords: "uncertain" or "uncertainty; "economy" or "economic"; and one of the policy term from t following keywords: "deficit", "Congress", "Federal Reserve", "regulation", "legislation" or "white house" including some other variants like "uncertainties", "the Fed" or "regulatory". EPU Index has been made by standardizing each newspaper series to a unit standard deviation and then average across the ten papers by month. Final index values have been achieved by normalizing the 10-paper series to a mean of 100 (Baker et al., 2016). The reason behind using such index for our analysis is that it captures uncertainty about what economic policy actions will be undertaken by whom and when, and also capture both near-term concerns like adjusting policy rates and longer-term concerns like funding policy for different programs (Baker et al., 2016). For different corporates it was found an inverse relationship between uncertainty and ROI which shows the same trends seen across many industries (Bates et al., 2009; Duchin, 2010; Im, Park, \& Zhao, 2017).

The measurement of each determinant is presented in Table 1.

Table 1. Measures of dependent and independent variables

\begin{tabular}{|l|l|l|}
\hline \multicolumn{1}{|c|}{ Variables } & \multicolumn{1}{|c|}{ Measurement } & \multicolumn{1}{c|}{ Reference } \\
\hline $\begin{array}{l}\text { Performance (ROA) } \\
\text { (Dependent Variable) }\end{array}$ & $\frac{\text { Revenue }}{\text { Assets }}$ & $\begin{array}{l}\text { Khrawish (2011); Ongore and Kusa (2013); } \\
\text { Hussain and Hadi (2017); Ghosh, Basit, and } \\
\text { Hassan (2017) }\end{array}$ \\
\hline $\begin{array}{l}\text { Uncertainty } \\
\text { (Independent Variable) }\end{array}$ & $\begin{array}{l}\text { Economic Policy } \\
\text { Uncertainty Index }\end{array}$ & Baker et al. (2016); Colombo (2013) \\
\hline $\begin{array}{l}\text { Size } \\
\text { (Independent Variable) }\end{array}$ & Log. of Total Assets & $\begin{array}{l}\text { Griffin and Mahon (1997); Cornett, Marcus, and } \\
\text { Tehranian (2008); Richard, Barnett, Dwyer, and } \\
\text { Chadwick (2004) }\end{array}$ \\
\hline $\begin{array}{l}\text { Growth } \\
\text { (Independent Variable) }\end{array}$ & $\frac{\text { Revenue }}{\text { Revenue }}$-1 & $\begin{array}{l}\text { Lev, Petrovits, and Radhakrishnan (2010); } \\
\text { Odagiri (1983); Williamson (1966) }\end{array}$ \\
\hline $\begin{array}{l}\text { Leverage } \\
\text { (Independent Variable) }\end{array}$ & $\frac{\text { Total Liabilities }}{\text { Total Equity }}$ & $\begin{array}{l}\text { Bhandari (1988); Barbee, Mukherji, and Raines } \\
\text { (1996); Duke and Hunt (1990) }\end{array}$ \\
\hline $\begin{array}{l}\text { Cital Intensity } \\
\text { (Independent Variable) }\end{array}$ & $\frac{\text { Total Asset }}{\text { Sales }}$ & $\begin{array}{l}\text { Stickney and McGee (1982); Cole and Elliott } \\
\text { (2005); Arai (2003) }\end{array}$ \\
\hline
\end{tabular}

On the basis of the previous discussion, the following hypotheses were formulated:

H1: There is a negative relationship between uncertainty and cooperative financial performance.

H2: There is a negative relationship between size and cooperative financial performance. 
H3: There is a positive relationship between growth and cooperative financial performance

H4: There is a negative relationship between leverage and cooperative financial performance.

H5: There is a negative relationship between capital intensity and cooperative financial performance.

\section{Data and methodology}

In order to make an empirical analysis to test our hypotheses, we used the USDA database to create a sample of U.S. agro cooperatives during the study period of 2009 to 2017. USDA is the U.S. federal executive department provides many publications, reports and educational materials on agriculture and rural development. USDA reports help us to track the different agro cooperatives over the sample. The data has been extracted for 9 years. The final panel dataset has been constructed as follows. Firstly, the firm-years during the study period which have missing values for any of the six variables were eliminated. Then from these agricultural cooperatives, during the study period, we select only those who have all 9 year continuous time series data observations. After that, if any value which comes with very high or low significance and also not follows the three standard deviation rule of the mean observation, also eliminated as outliers. These criteria provided us a dataset of 333 firm-year observations for different agro cooperatives over the 2009-2017 time periods. To make the dependent variable (ROA) normal concerning the mean and variance, we used natural log transformation in our analysis (Nevill \& Holder, 1995).

\section{Statistical analysis}

The study is based on a panel data set, which could result in biased estimations if conducting pooled-OLS. (Greene, 1997). In order to deal with the possible problems of heteroskedasticity and autocorrelation three test statistics were used, which guided us for the selection of appropriate specific methods. The first test is used in our study was Breusch and Pagan's Lagrange multiplier test, which helps us to choose the appropriate test among the Panel data assessment or Pooled OLS (Breusch \& Pagan, 1980). As per Breusch and Pagan (1980), the Lagrange multiplier test shows the consideration of panel data estimations at the significance level of 0.05 (Lagrange multiplier (LM) value is 228.793 , the p-value is 0.000). The second test is the Hausman test, to assess which model is appropriate, fixed effects model or random effects model (Hausman, 1978). The results of the Hausman test indicate Chi $2=34.76$, $\mathrm{p}$-value $=0.000$, resulting in that fixed effect model is appropriate for our analysis at the significance level of 0.05. Finally, the Wooldridge test is used to check for serial correlation, which biases the standard errors and causes the results to be less efficient (Wooldridge, 2010). The computed F value of Wooldridge test is 126.528 , p-value $=$ 0.000 , which falls into the serial correlation area. As the Wooldridge test statistics indicate a significant autocorrelation in our panel model, we employ the first order autoregressive (AR[1]) fixed effect model to control the serial correlation which also can be used for idiosyncratic risk (Hoechle, 2007). 
The equation below represents the model used in the estimation (Gujarati, 2009).

$$
\begin{aligned}
& \ln (R O A)=\alpha 0+\alpha 1(\text { Uncertainty })+\alpha 2 \ln (\text { Size })+\alpha 3(\text { Growth })+ \\
& \alpha 4(\text { Leverage })+\alpha 5(\text { Capital Intensity })+\varepsilon .
\end{aligned}
$$

\section{Results}

Below the Table 2 shows the descriptive statistics of ROA for the U.S. agricultural cooperatives which have been identified over the 9 years' time period.

Table 2. Return on Asset (ROA) of U.S. agricultural cooperatives over time

\begin{tabular}{|c|c|c|c|c|c|c|}
\hline Year & Observation & Mean & $\begin{array}{c}\text { Standard } \\
\text { Deviation }\end{array}$ & Minimum & Median & Maximum \\
\hline 2009 & 37 & 1.19 & 0.61 & -0.05 & 1.19 & 3.41 \\
\hline 2010 & 37 & 1.17 & 0.59 & -0.02 & 1.11 & 3.46 \\
\hline 2011 & 37 & 1.18 & 0.58 & 0.23 & 1.05 & 3.26 \\
\hline 2012 & 37 & 1.21 & 0.56 & 0.13 & 1.19 & 3.33 \\
\hline 2013 & 37 & 1.22 & 0.46 & 0.05 & 1.31 & 2.22 \\
\hline 2014 & 37 & 1.22 & 0.62 & -0.04 & 1.21 & 3.27 \\
\hline 2015 & 37 & 1.11 & 0.61 & -0.11 & 1.05 & 3.33 \\
\hline 2016 & 37 & 0.98 & 0.60 & -0.12 & 0.95 & 3.40 \\
\hline 2017 & 37 & 1.02 & 0.66 & -0.16 & 0.95 & 3.38 \\
\hline Total & 333 & 1.14 & 0.59 & -0.16 & 1.11 & 3.46 \\
\hline
\end{tabular}

As per Table 2 the average ROA for U.S. agro cooperatives is 1.14, which states that U.S. agro cooperatives normally had positive returns. However, this value is higher than those of industries and publicly traded U.S. firms which have been noticed by previous literature. As per Waddock and Graves (1997), the mean ROA for U.S. firms from 2004 to 2006 was 0.055 to 0.139. In Gartenberg, Prat, and Serafeim's (2016) study, the mean ROA for U.S. firms from 2006 to 2011 is 0.10 . Throughout the study period, a specific increasing pattern can be seen in the ROI for the selected U.S. agricultural cooperatives.

The values of descriptive statistics for different variables are provided in Table 3 . In this table, it is observed that the mean ratio of ROA is 1.14 and the standard deviation is 0.59 , which means there is a less right-skewed distribution for ROA. The mean value of the uncertainty index is 2.12 and the standard deviation is 0.07 , indicate less variance in economic policy uncertainty. For the firm size, the mean value is 1076.01 million USD, and the standard deviation is 2472.06 million USD indicate a wide variance among all the cooperatives. Because having such a wide variance, we used natural log values of total assets in our analysis. The mean value of growth is 0.04 ; indicates $4 \%$ average annual growth in the revenue of the selected cooperatives. The mean of the leverage is 0.23 ; reveals that U.S. agricultural cooperatives do not very much rely on debt and preferred to use equity than debt. For capital intensity, the average value is 0.37 suggesting that the U.S. agricultural cooperatives are generating positive revenues on their assets. 
Table 3. Descriptive statistics

\begin{tabular}{|l|c|c|c|c|c|c|}
\hline \multicolumn{1}{|c|}{ Variable } & $\mathrm{N}$ & Mean & $\begin{array}{c}\text { Standard } \\
\text { Deviation }\end{array}$ & Minimum & Median & Maximum \\
\hline ROA & 333 & 1.14 & 0.59 & -0.16 & 1.11 & 3.46 \\
\hline Uncertainty & 333 & 2.12 & 0.07 & 1.96 & 2.15 & 2.19 \\
\hline Size (in Million USD) & 333 & 1076.01 & 2427.06 & 30 & 378 & 17318 \\
\hline Growth & 333 & 0.04 & 0.22 & -0.64 & 0.00 & 2.44 \\
\hline Leverage & 333 & 0.23 & 0.01 & 0.19 & 0.23 & 0.25 \\
\hline Capital Intensity & 333 & 0.37 & 0.20 & 0.03 & 0.33 & 1.17 \\
\hline
\end{tabular}

Before applying the Panel regression model statistics, we used the Pearson correlation coefficient for examining the independent variable's association with the ratio of ROA.

$$
r=\frac{\sum\left(X_{i}-\bar{X}\right)\left(Y_{i}-\bar{Y}\right)}{\left[\sum\left(X_{i}-\bar{X}\right)^{2} \sum\left(Y_{i}-\bar{Y}\right)^{2}\right]^{1 / 2}},
$$

where, $r$ - Pearson correlation coefficient, $X_{i}$ and $Y_{i}$ - Values of any two variables for the $i^{\text {th }}$ observation (Lee Rodgers \& Nicewander, 1988).

In Table 4 we see that there is a positive and significant correlation between ROA and Growth. On the other side, ROA is negatively and significantly associated with Size, Leverage, and Capital Intensity.

Table 4. Pearson correlation coefficients

\begin{tabular}{|l|c|c|c|c|c|c|}
\hline & ROA & Uncertainty & Size & Growth & Leverage & $\begin{array}{c}\text { Capital } \\
\text { Intensity }\end{array}$ \\
\hline ROA & 1.000 & -0.017 & $-0.125^{*}$ & $0.161^{* *}$ & $-0.312^{* *}$ & $-0.527^{* *}$ \\
\hline Uncertainty & -0.017 & 1.000 & -0.012 & $0.144^{* *}$ & $0.227^{* *}$ & 0.012 \\
\hline Size & $-0.125^{*}$ & -0.012 & 1.000 & -0.027 & $0.119^{*}$ & $0.129^{*}$ \\
\hline Growth & $0.161^{* *}$ & $0.144^{* *}$ & -0.027 & 1.000 & $0.206^{* *}$ & $-0.109^{*}$ \\
\hline Leverage & $-0.312^{* *}$ & $0.227^{* *}$ & $0.119^{*}$ & $0.206^{* *}$ & 1.000 & $0.135^{*}$ \\
\hline Capital Intensity & $-0.527^{* *}$ & 0.012 & $0.129^{*}$ & $-0.109^{*}$ & $0.135^{*}$ & 1.000 \\
\hline
\end{tabular}

* Significant at the 0.05 level.

** Significant at the 0.01 level.

Table 5 provides the panel regression model results in which we identified the factors which can affect the financial performance of cooperatives. The F statistics 211.34 , with significance level 0.01 indicates that the model is significant and able to clarifying all the determinants which we have taken in our study to see the impact on selected cooperatives. The value of overall R-square is 0.81 showing all five variables have described $81 \%$ disparity in the financial performance of agro cooperatives. The positive coefficients of t-statistic for Growth indicate that the financial performance is positively affected by growth. The negative coefficient of Uncertainty, Size, and Capital Intensity indicate that financial performance is 
negatively affected by uncertainty, size, and capital intensity. Leverage is not found statistically significant at the 0.05 significance level.

Table 5. Panel Regression Analysis by using Fixed effect Model

(AR[1]) Fixed Effect Model, Lagrange multiplier $(\mathrm{LM})$ test $(\mathrm{BP}): 228.793^{*}(\mathrm{p}$-value $=0.000)$; Hausman test: $\mathrm{Chi}^{2}=34.76^{*}(\mathrm{p}$-value $=0.000) ;$ Wooldridge test statistics: F-value $=126.528(\mathrm{p}$-value $=0.000)$

\begin{tabular}{|l|c|c|c|c|}
\hline \multicolumn{1}{|c|}{ Variable } & Coefficient & Std. Error & t-Statistic & Prob. \\
\hline Constant & 1.475 & 0.125 & 11.71 & 0.000 \\
\hline Uncertainty & -0.091 & 0.034 & $-2.61^{* *}$ & 0.003 \\
\hline Size & -0.075 & 0.012 & $-6.07^{* *}$ & 0.000 \\
\hline Growth & 0.050 & 0.010 & $4.58^{* *}$ & 0.000 \\
\hline Leverage & -0.035 & 0.170 & -0.21 & 0.934 \\
\hline Capital Intensity & -0.89 & 0.039 & $-22.54^{* *}$ & 0.000 \\
\hline \multicolumn{1}{|c|}{$\mathrm{R}^{2}$} & Within $(0.78)$ & Between $(0.81)$ & Overall $(0.81)$ & \\
\hline F-statistic & $211.34^{* *}$ & & & \\
\hline Prob(F-statistic) & 0.0000 & & & \\
\hline
\end{tabular}

* Significant at the 0.05 level.

** Significant at the 0.01 level.

Note: The dependent variable (ROA), the ratio of revenue to total assets (in natural logarithm); Uncertainty, the index of economic policy uncertainty; Size, the log of total assets; Growth, the ratio of revenue $^{t}$ to revenue ${ }^{t-1}$ minus one; Leverage, the ratio of total liabilities to total equity; Capital Intensity, the ratio of total asset to sales.

Software used: Stata 15.1 .

\section{Discussion}

Results suggest that the U.S. agro cooperatives are found highly sensitive to economic policy uncertainty, proposing that uncertainty may be a key explanatory variable for agricultural cooperatives (Contractor \& Lorange, 1988). In the panel regression analysis, the negative coefficient of Uncertainty contributes to the literature regarding uncertainty and firm performance (Miyagiwa \& Ohno, 2002). First, we add to the literature about firm performance, including Franken and Cook (2015), Karami and Rezaei-Moghaddam (2005) and Sawyerr, McGee, and Peterson (2003). We find that a firm faces uncertainty has a significant influence on its performance. To our knowledge, this is the first study of agricultural cooperatives to examine the relationship between uncertainty and financial performance. The literature emphasizes that as per risk aversion and incomplete knowledge about the market, the relationship between uncertainty and agro cooperative performance found negative (e.g., Craine, 1989; Zeira, 1990). The negative coefficient of Size indicates that small agro cooperatives yield higher average returns than large agro cooperatives even when their uncertainty is equal. Furthermore, Hart and Moore (1996) also found that as cooperatives size increases, the cooperative form of organizations becomes relatively less efficient because business and preferences become more heterogeneous among members after moving from investor-oriented firm to larger firms. The only positive coefficient of Growth supports the notion that 
a significant and positive impact exists between growth and financial performance of agro cooperatives (Belderbos, Carree, \& Lokshin, 2004). Agro cooperatives have a stronger incentive to hold higher returns on the asset as due to their increased productivity and growth they incur higher sales (McGee, Dowling, \& Megginson, 1995). Leverage has statistically insignificant results. This negative and not statistically significant relationship does support the previous arguments that due to leverage higher rate of bankruptcy and default risk would arise (Ferreira \& Vilela, 2004). Finally, the Capital Intensity which is the ratio of assets to sales explains the amount of capital needed per dollar of revenue and is positively related to the firm performance (Frederick H. deB. Harris, 1988). But in our model capital intensity also found to have a negative but significant variable which states that less capital intensive agro cooperatives have higher profitability than higher capital-intensive firms. However, the small firm effect may be a reason for such association between capital intensity and financial performance of agro cooperatives (Lerman \& Parliament, 1990).

\section{Conclusions}

Following the results presented above, it can be concluded that there are certain micro as well as macroeconomic determinants that influence agro-cooperatives' performance in a significant manner. Whereas prior work mostly focused on micro determinants, we also investigate the possibility of macro aspect namely, in our case, economic policy uncertainty. Conducted research allowed the formulation of the following conclusions. While making policy decisions, agro cooperatives should be alert of the fact that the uncertainty surrounding these decisions can be just as adverse as making the wrong decision. The results also suggest that economic policy uncertainty in the U.S. in recent years may have harmed the agro cooperatives' performance. Our findings are broadly consistent with the conceptual frameworks that highlight the adverse effect of uncertainty shocks on firm performance. The negative coefficient of Size indicates that small agro cooperatives usually earn higher rate of return on asset than large asset rich cooperative firms. With respect to size, it could be hypothesized that small agro cooperatives, with a relatively small asset base, prefer to maintain higher liquidity and have a better market access ability than large firms (Lerman \& Parliament, 1991). Growth is found positively associated with performance, support the fact that growth is always a necessary condition of positive performance for all firms (Birley \& Westhead, 1990). Mergers and acquisitions can be a reason for persistent trend of growth among agro cooperatives (Lerman \& Parliament, 1991). The hypothesized negative relationship between capital intensity and agro cooperative performance appears to be supported by the data. Findings from the overall sample of U.S. agro cooperatives supported all the five initial hypotheses. The findings have important implications for agricultural development policymakers and experts to deal with all such micro and macro determinants that might impact the performance of these agro cooperative firms. The data used in this study have some limitations, as the available data from USDA include only 37 U.S. agricultural cooperatives. Future studies should include more agro cooperatives to generalize the findings by employing some other specific variables like Government support component, product mix, and market characteristics, etc. In addition to this, future studies can make their focus on other cooperatives also. 


\section{References}

Acharya, V. V., Almeida, H., \& Campello, M. (2013). Aggregate risk and the choice between cash and lines of credit. The Journal of Finance, 68(5), 2059-2116. https://doi.org/10.1111/jofi.12056

Amat, O., \& Perramon, J. (2011). High-growth cooperatives: Financial profile and key factors for competitiveness. Retrieved from https://repositori.upf.edu/bitstream/handle/10230/19904/1289. pdf? sequence $=1$

Antonakakis, N., Chatziantoniou, I., \& Filis, G. (2013). Dynamic co-movements of stock market returns, implied volatility and policy uncertainty. Economics Letters, 120(1), 87-92. https://doi.org/10.1016/j.econlet.2013.04.004

Arai, M. (2003). Wages, profits, and capital intensity: Evidence from matched worker-firm data. Journal of Labor Economics, 21(3), 593-618. https://doi.org/10.1086/374960

Baker, S. R., Bloom, N., \& Davis, S. J. (2016). Measuring economic policy uncertainty. The Quarterly Journal of Economics, 131(4), 1593-1636. https://doi.org/10.1093/qje/qjw024

Barbee Jr, W. C., Mukherji, S., \& Raines, G. A. (1996). Do sales-price and debt-equity explain stock returns better than book-market and firm size? Financial Analysts Journal, 52(2), 56-60. https://doi.org/10.2469/faj.v52.n2.1980

Bates, T. W., Kahle, K. M., \& Stulz, R. M. (2009). Why do US firms hold so much more cash than they used to?. The Journal of Finance, 64(5), 1985-2021. https://doi.org/10.1111/j.1540-6261.2009.01492.x

Belderbos, R., Carree, M., \& Lokshin, B. (2004). Cooperative R\&D and firm performance. Research policy, 33(10), 1477-1492. https://doi.org/10.1016/j.respol.2004.07.003

Beranová, M., \& Basovníková, M. (2014). Components of the financial performance of agricultural enterprises. Acta Universitatis Agriculturae et Silviculturae Mendelianae Brunensis, 59(7), 57-68. https://doi.org/10.11118/actaun201159070057

Bhandari, L. C. (1988). Debt/equity ratio and expected common stock returns: Empirical evidence. The Journal of Finance, 43(2), 507-528. https://doi.org/10.1111/j.1540-6261.1988.tb03952.x

Birchall, J., \& Ketilson, L. H. (2009). Resilience of the cooperative business model in times of crisis. International Labour Office, Sustainable Enterprise Programme. Geneva: ILO.

Birley, S., \& Westhead, P. (1990). Growth and performance contrasts between 'types' of small firms. Strategic Management Journal, 11(7), 535-557. https://doi.org/10.1002/smj.4250110705

Bonus, H. (1986). The cooperative association as a business enterprise: a study in the economics of transactions. Journal of Institutional and Theoretical Economics (JITE)/Zeitschrift für die gesamte Staatswissenschaft, 142(2), 310-339.

Breusch, T. S., \& Pagan, A. R. (1980). The Lagrange multiplier test and its applications to model specification in econometrics. The Review of Economic Studies, 47(1), 239-253. https://doi.org/10.2307/2297111

Caves, R. E., \& Petersen, B. C. (1986). Cooperatives' tax "advantages": Growth, retained earnings, and equity rotation. American Journal of Agricultural Economics, 68(2), 207-213. https://doi.org/10.2307/1241422

Chaddad, F. R., Cook, M. L., \& Heckelei, T. (2005). Testing for the presence of financial constraints in US agricultural cooperatives: an investment behaviour approach. Journal of Agricultural Economics, 56(3), 385-397. https://doi.org/10.1111/j.1477-9552.2005.00027.x

Cole, M. A., \& Elliott, R. J. (2005). FDI and the capital intensity of "dirty" sectors: a missing piece of the pollution haven puzzle. Review of Development Economics, 9(4), 530-548. https://doi.org/10.1111/j.1467-9361.2005.00292.x

Colombo, V. (2013). Economic policy uncertainty in the US: Does it matter for the Euro area? Economics Letters, 121(1), 39-42. https://doi.org/10.1016/j.econlet.2013.06.024 
Contractor, F. J., \& Lorange, P. (1988). Why should firms cooperate? The strategy and economics basis for cooperative ventures. Cooperative Strategies in International Business, 1, 3-30.

Cook, M. L. (1995). The future of US agricultural cooperatives: A neo-institutional approach. American Journal of Agricultural Economics, 77(5), 1153-1159. https://doi.org/10.2307/1243338

Cornett, M. M., Marcus, A. J., \& Tehranian, H. (2008). Corporate governance and pay-for-performance: The impact of earnings management. Journal of Financial Economics, 87(2), 357-373. https://doi.org/10.1016/j.jfineco.2007.03.003

Craine, R. (1989). Risky business: the allocation of capital. Journal of Monetary Economics, 23(2), 201218. https://doi.org/10.1016/0304-3932(89)90048-2

Deininger, K. (1995). Collective agricultural production: A solution for transition economies?. World Development, 23(8), 1317-1334. https://doi.org/10.1016/0305-750X(95)00044-D

Duchin, R. (2010). Cash holdings and corporate diversification. The Journal of Finance, 65(3), 955-992. https://doi.org/10.1111/j.1540-6261.2010.01558.x

Duke, J. C., \& Hunt III, H. G. (1990). An empirical examination of debt covenant restrictions and accounting-related debt proxies. Journal of Accounting and Economics, 12(1-3), 45-63. https://doi.org/10.1016/0165-4101(90)90041-2

Ferreira, M. A., \& Vilela, A. S. (2004). Why do firms hold cash? Evidence from EMU countries. European Financial Management, 10(2), 295-319. https://doi.org/10.1111/j.1354-7798.2004.00251.x

FitzRoy, F. R., \& Kraft, K. (1987). Cooperation, productivity, and profit sharing. The Quarterly Journal of Economics, 102(1), 23-35. https://doi.org/10.2307/1884678

Foley, C. F., Hartzell, J. C., Titman, S., \& Twite, G. (2007). Why do firms hold so much cash? A taxbased explanation. Journal of Financial Economics, 86(3), 579-607. https://doi.org/10.1016/j.jfineco.2006.11.006

Franken, J. R., \& Cook, M. L. (2015). Informing measurement of cooperative performance. In Interfirm Networks (pp. 209-226). Cham: Springer.

Frederick H. deB. Harris. (1988). Capital intensity and the firm's cost of capital. The Review of Economics and Statistics, 70(4), 587-594. https://doi.org/10.2307/1935821

Gao, J., Grinstein, Y., \& Wang, W. (2014). Cash holdings, precautionary motives, and systematic uncertainty. SSRN. https://doi.org/10.2139/ssrn.2478349

Gartenberg, C. M., Prat, A., \& Serafeim, G. (2016). Corporate purpose and financial performance. Retrieved from dash.harvard.edu/bitstream/handle/1/30903237/17-023.pdf? sequence $=1$ https://doi.org/10.2139/ssrn.2840005

Ghosh, B., Basit, A., \& Hassan, Z. (2017). Impact of corporate social responsibility on financial performance: A study on manufacturing companies listed in London Stock Exchange (LSE)-UK. International Journal of Accounting \& Business Management, 5(2), 2289-4519.

Grashuis, J. (2018). A quantile regression analysis of farmer cooperative performance. Agricultural Finance Review, 78(1), 65-82. https://doi.org/10.1108/AFR-05-2017-0031

Greene, W. H. (1997). Econometric analysis (3rd ed.). New Yersey: Prentice-Hall International.

Griffin, J. J., \& Mahon, J. F. (1997). The corporate social performance and corporate financial performance debate: Twenty-five years of incomparable research. Business \& Society, 36(1), 5-31. https://doi.org/10.1177/000765039703600102

Gujarati, D. N. (2009). Basic econometrics (5 ${ }^{\text {th }}$ ed.). New York: McGraw-Hill.

Hansmann, H. (1988). Ownership of the Firm. Journal of Law, Economics, \& Organization, 4(2), $267-$ 304.

Harris, F. H. D. (1994). Asset specificity, capital intensity and capital structure: an empirical test. Managerial and Decision Economics, 15(6), 563-576. https://doi.org/10.1002/mde.4090150604 
Hart, O., \& Moore, J. (1996). The governance of exchanges: members' cooperatives versus outside ownership. Oxford Review of Economic Policy, 12(4), 53-69. https://doi.org/10.1093/oxrep/12.4.53

Hausman, J. A. (1978). Specification tests in econometrics. Econometrica: Journal of the Econometric Society, 1251-1271. https://doi.org/10.2307/1913827

Hoechle, D. (2007). Robust standard errors for panel regressions with cross-sectional dependence. Stata Journal, 7(3), 281. https://doi.org/10.1177/1536867X0700700301

Hussain, M. A., \& Hadi, A. R. (2017). Corporate governance and firm performance: Evidence from CIDB Malaysia. American Journal of Research Communication, 5(12), 1-21.

Im, H., Park, H., \& Zhao, G. (2017). Uncertainty and the value of cash holdings. Economics Letters, 155, 43-48. https://doi.org/10.1016/j.econlet.2017.03.005

International Labor Organization (2014). The cooperative way of doing business. Sustainable enterprise programme, (pp.3-4). ILO.

Kang, W., \& Ratti, R. A. (2013). Oil shocks, policy uncertainty and stock market return. Journal of International Financial Markets, Institutions and Money, 26, 305-318. https://doi.org/10.1016/j.intfin.2013.07.001

Karami, E., \& Rezaei-Moghaddam, K. (2005). Modeling determinants of agricultural production cooperatives' performance in Iran. Agricultural Economics, 33(3), 305-314. https://doi.org/10.1111/j.1574-0864.2005.00069.x

Khrawish, H. A. (2011). Determinants of commercial banks performance: Evidence from Jordan. International Research Journal of Finance and Economics, 5(5), 19-45.

Kim, C. S., Mauer, D. C., \& Sherman, A. E. (1998). The determinants of corporate liquidity: Theory and evidence. Journal of Financial and Quantitative Analysis, 33(3), 335-359. https://doi.org/10.2307/2331099

Kontogeorgos, A., Sergaki, P., Kosma, A., \& Semou, V. (2018). Organizational models for agricultural cooperatives: empirical evidence for their performance. Journal of the Knowledge Economy, 9(4), 1123-1137. https://doi.org/10.1007/s13132-016-0402-8

Lee Rodgers, J., \& Nicewander, W. A. (1988). Thirteen ways to look at the correlation coefficient. The American Statistician, 42(1), 59-66. https://doi.org/10.2307/2685263

Lerman, Z., \& Parliament, C. (1990). Comparative performance of cooperatives and investor-owned firms in US food industries. Agribusiness, 6(6), 527-540. https://doi.org/10.1002/1520-6297(199011)6:6<527::AID-AGR2720060602>3.0.CO;2-R

Lerman, Z., \& Parliament, C. (1991). Size and industry effects in the performance of agricultural cooperatives. Agricultural Economics, 6(1), 15-29. https://doi.org/10.1016/0169-5150(91)90013-B

Lev, B., Petrovits, C., \& Radhakrishnan, S. (2010). Is doing good good for you? How corporate charitable contributions enhance revenue growth. Strategic Management Journal, 31(2), 182-200.

Levy, H., \& Lerman, Z. (1985). Testing P/E rations filters with stochastic dominance. The Journal of Portfolio Management, 11(2), 31-40. https://doi.org/10.3905/jpm.1985.31

Liebrand, C. (2007). Measuring the performance of agricultural cooperatives. Retrieved from http://www. uwcc.wisc.edu/pdf/measuring\%20ag\%20coop\%20performance.pdf

Liu, L., \& Zhang, T. (2015): Economic policy uncertainty and stock market volatility. Finance Research Letters, 15, 99-105. https://doi.org/10.1016/j.frl.2015.08.009

Martinkute-Kauliene, R. (2012). Exotic options: a chooser option and its pricing. Business, Management and Education, 10(2), 289-301. https://doi.org/10.3846/bme.2012.20

Martinkute-Kauliene, R. (2014). Risk factors in derivatives markets. Entrepreneurial Business and Economics Review, 2(4), 71-83. https://doi.org/10.15678/EBER.2014.020405 
McGee, J. E., Dowling, M. J., \& Megginson, W. L. (1995). Cooperative strategy and new venture performance: The role of business strategy and management experience. Strategic Management Journal, 16(7), 565-580. https://doi.org/10.1002/smj.4250160706

Mishra, A. K., \& Morehart, M. J. (2001). Factors affecting returns to labor and management on US dairy farms. Agricultural Finance Review, 61(2), 123-140. https://doi.org/10.1108/00214790180001120

Miyagiwa, K., \& Ohno, Y. (2002). Uncertainty, spillovers, and cooperative R\&D. International Journal of Industrial Organization, 20(6), 855-876. https://doi.org/10.1016/S0167-7187(01)00079-0

Nevill, A. M., \& Holder, R. L. (1995). Scaling, normalizing, and per ratio standards: an allometric modeling approach. Journal of Applied Physiology, 79(3), 1027-1031. https://doi.org/10.1152/jappl.1995.79.3.1027

Odagiri, H. (1983). R \& D expenditures, royalty payments, and sales growth in Japanese manufacturing corporations. The Journal of Industrial Economics, 32(1), 61-71. https://doi.org/10.2307/2097986

Ongore, V. O., \& Kusa, G. B. (2013). Determinants of financial performance of commercial banks in Kenya. International Journal of Economics and Financial Issues, 3(1), 237-252.

Opler, T., Pinkowitz, L., Stulz, R., \& Williamson, R. (1999). The determinants and implications of corporate cash holdings. Journal of Financial Economics, 52(1), 3-46. https://doi.org/10.1016/S0304-405X(99)00003-3

Ozkan, A., \& Ozkan, N. (2004). Corporate cash holdings: An empirical investigation of UK companies. Journal of Banking \& Finance, 28(9), 2103-2134. https://doi.org/10.1016/j.jbankfin.2003.08.003

Pinkowitz, L., \& Williamson, R. (2001). Bank power and cash holdings: Evidence from Japan. The Review of Financial Studies, 14(4), 1059-1082. https://doi.org/10.1093/rfs/14.4.1059

Pinkowitz, L., Stulz, R. M., \& Williamson, R. (2012). Multinationals and the high cash holdings puzzle (No. w18120). National Bureau of Economic Research. https://doi.org/10.3386/w18120

Rakopoulos, T. (2014). The crisis seen from below, within, and against: from solidarity economy to food distribution cooperatives in Greece. Dialectical Anthropology, 38(2), 189-207. https://doi.org/10.1007/s10624-014-9342-5

Richard, O. C., Barnett, T., Dwyer, S., \& Chadwick, K. (2004). Cultural diversity in management, firm performance, and the moderating role of entrepreneurial orientation dimensions. Academy of Management Journal, 47(2), 255-266.

Rothschild, J., \& Whitt, J. A. (1989). The cooperative workplace: Potentials and dilemmas of organisational democracy and participation. CUP Archive.

Sawyerr, O. O., McGee, J., \& Peterson, M. (2003). Perceived uncertainty and firm performance in SMEs: The role of personal networking activities. International Small Business Journal, 21(3), 269-290. https://doi.org/10.1177/02662426030213002

Schneiberg, M., King, M., \& Smith, T. (2008). Social movements and organizational form: Cooperative alternatives to corporations in the American insurance, dairy, and grain industries. American Sociological Review, 73(4), 635-667. https://doi.org/10.1177/000312240807300406

Schuh, G. E. (1974). The exchange rate and US agriculture. American Journal of Agricultural Economics, 56(1), 1-13. https://doi.org/10.2307/1239342

Shannon, F. A. (2017). The farmer's last frontier: Agriculture, 1860-1897. Routledge.

Sisay, D. T., Verhees, F. J., \& Van Trijp, H. C. (2017). The influence of market orientation on firm performance and members' livelihood in Ethiopian seed producer cooperatives. Agrekon, 56(4), 366-382. https://doi.org/10.1080/03031853.2017.1409126

Staatz, J. M. (1987). Farmers' incentives to take collective action via cooperatives: a transaction cost approach. Cooperative Theory: New Approaches, 18, 87-107. 
Stickney, C. P., \& McGee, V. E. (1982). Effective corporate tax rates the effect of size, capital intensity, leverage, and other factors. Journal of Accounting and Public Policy, 1(2), 125-152. https://doi.org/10.1016/S0278-4254(82)80004-5

USDA. (2011). Understanding cooperatives: Farmer cooperative statistics. Cooperative information report 45, Section 13. Retrieved from https://www.rd.usda.gov/files/CIR45-13.pdf

Waddock, S. A., \& Graves, S. B. (1997). The corporate social performance-financial performance link. Strategic Management Journal, 18(4), 303-319. https://doi.org/10.1002/(SICI)1097-0266(199704)18:4<303::AID-SMJ869>3.0.CO;2-G

Williamson, J. (1966). Profit, growth and sales maximization. Economica, 33(129), 1-16. https://doi.org/10.2307/2552269

Wooldridge, J. M. (2010). Econometric analysis of cross section and panel data. MIT press.

Zeira, J. (1990). Cost uncertainty and the rate of investment. Journal of Economic Dynamics and Control, 14(1), 53-63. https://doi.org/10.1016/0165-1889(90)90005-2 